\title{
ANALISIS KENAIKAN TAGIHAN LISTRIK SELAMA PENDEMI COVID-19 BERDASARKAN PERILAKU KONSUMTIF ENERGI LISTRIK DI INDONESIA
}

\author{
Rosyid Ridlo Al Hakim ${ }^{1,2}$, Ropiudin ${ }^{3}$, Achmad Muchsin ${ }^{4}$, Faridah Satya Lestari ${ }^{5}$ \\ Magister Teknik Elektro, Fakultas Teknik dan Ilmu Komputer, Universitas Global Jakarta ${ }^{1}$ \\ Fakultas Biologi, Universitas Jenderal Soedirman ${ }^{2}$ \\ Laboratorium Sistem Termal, Fakultas Pertanian, Universitas Jenderal Soedirman ${ }^{3}$ \\ Fakultas Syariah, Institut Agama Islam Negeri Purwokerto ${ }^{4}$ \\ Fakultas Ekonomi dan Bisnis, Universitas Jenderal Soedirman ${ }^{5}$ \\ Email: \\ rosyidridlo@student.jgu.ac.id, faridahsatyalestari@gmail.com
}

\begin{abstract}
Abstrak
Sejumlah pelanggan PLN mengeluhkan akan kenaikan tagihan listrik pada awal Juli 2020. Sejak awal Juli lalu, banyak keluhan masyarakat tentang naiknya tagihan listrik selagi pandemi Covid-19 di Indonesia. Skema tagihan listrik ini menggunakan $40 \%$ pada Bulan Juni 2020, yang kemudian baru dibayarkan secara bertahap pada Bulan Juli, Agustus, September. Adanya kenaikan tagihan dikarenakan perubahan perilaku masyarakat yang menggunakan listrik selama pandemi Covid-19. Metode penelitian kuantitatif dengan teknik pengambilan sampel secara random sampling. Hasil sebanyak 137 orang yang mengalami kenaikan tagihan $(90,5 \%)$ dengan $67,9 \%$ responden merupakan pelanggan prabayar, dan kenaikan tagihan listrik yang diakibatkan oleh aktivitas-aktivitas yang lebih mengkonsumsi daya listrik yakni lebih sering berada di depan komputer/laptop dan terhubung ke internet sebanyak 28,5\%, menonton TV/Film sebanyak $11,7 \%$, membuka platform daring multimedia sebanyak $9.5 \%$. Nilai skala ordinal dari perilaku yang tergolong dalam kategori lebih banyak menggunakan energi listrik cukup berpengaruh terhadap tagihan listrik (kategori A1) 2,883 yang berarti cukup. Perlunya kesadaran masyarakat akan upaya-upaya untuk menghemat energi listrik selama pandemi Covid-19 (Work from Home) dan agar selalu melakukan pengecekan berkala pada penggunaan listrik di rumah.
\end{abstract}

Kata kunci: Covid-19, Energi, Listrik, Perilaku Konsumtif, Tagihan

\section{PENDAHULUAN}

Manusia menggunakan listrik untuk menunjang kegiatan sehari-hari (Đurišić et al., 2019). Listrik yang ada di Indonesia, seluruhnya dikelola oleh BUMN yakni PLN, atau Perusahaan Listrik Negara. Energi listrik yang dikelola oleh PLN tersebut, dihasilkan dari pembangkit-pembangkit listrik yang memanfaatkan sumber energi yang dapat diperbaharui (contoh, PLTA) dan juga berasal dari sumber energi yang tidak dapat diperbaharui (contoh, PLTU, PLTD). Suplai listrik di Indonesia 60\%-nya masih menggunakan pembangkit listrik yang berbahan bakar minyak, dan untuk menghasilkan $1 \mathrm{kWh}$ memerlukan sekitar 3 liter solar (Al Hakim, 2020a; Yuliati \& Nurasrina, 2012).

Akhir Desember 2019 awal mula kasus Covid-19 ditemukan di Wuhan, Cina. Tanggal 26 Januari 2020, terdapat lebih dari 2000 kasus infeksi pada manusia (Lu et al., 2020). WHO 
menetapkan status pandemi global bagi Covid-19 karena telah menyebar hingga ke seluruh dunia (Al Hakim, 2020b; Al Hakim et al., 2020; Sulistyaningrum \& Al Hakim, 2020). Dilansir dari portal berita kompas.com, sejumlah pelanggan mengeluhkan adanya kenaikan tagihan listrik sekitar awal Juli 2020 lalu. Sejak awal Juli lalu, banyak sekali keluhan masyarakat akan naiknya tagihan listrik selagi pandemi Covid-19. Skema tagihan listrik ini menggunakan $40 \%$ pada Bulan Juni 2020, yang kemudian baru dibayarkan secara bertahap pada Bulan Juli, Agustus, September. Menurut PLN sendiri adanya kenaikan tagihan dikarenakan perubahan perilaku masyarakat yang menggunakan listrik selama PSSB berlaku (Kompas, 2020).

PLN telah memberikan kategori pelanggan yang termasuk ke dalam lonjakan tagihan listrik, yakni (1) pelanggan yang tagihan listriknya naik melebihi 20\% dari tagihan bulan sebelumnya; (2) pelanggan yang tagihan pada bulan sebelumnya sudah dirata-rata sehingga hasilnya lebih kecil dari penggunaan listrik yang real; (3) pelanggan yang tagihan pada bulan sebelumnya tidak mendapatkan pengoreksian rekening listriknya (Kompas, 2020). Berdasarkan penjabaran tersebut, maka penelitian ini dilakukan dengan tujuan untuk menganalisis perilaku konsumtif masyarakat di Indonesia terkait dengan kenaikan tagihan listrik selama pandemi Covid-19, serta rekomendasi-rekomendasi untuk masyarakat agar dapat lebih menghemat listrik ke depannya.

\section{Energi Listrik di Indonesia}

Tercatat pada 2018, total produksi energi primer (TPEP) negara Indonesia terdiri atas minyak bumi, gas bumi, batu bara, dan energi terbarukan yang mencapai 411,6 MTOE (setara mega ton minyak). Sebesar 64\% atau sejumlah 261,4 MTOE dari TPEP tersebut diekspor terutama sumber energi batu bara dan LNG (gas alam cair, Liquefied Natural Gas). Disisi lain, Indonesia mengimpor energi terutama minyak mentah dan produk BBM mencapai 43,2 MTOE serta sejumlah kecil batu bara kalori tinggi yang diperlukan untuk memenuhi kebutuhan di sektor industri. Total konsumsi energi final (TKEF) yang tanpa biomassa tradisional pada tahun 2018 sekitar 114 MTOE terdiri atas sektor transportasi 40\%, industri 36\%, rumah tangga 16\%, komersial 6\%, dan sektor lainnya 2\% (Tim Sekretaris Jenderal Dewan Energi Nasional, 2019).

Kapasitas pembangkit tenaga listrik di Indonesia hingga 2018 mencapai 64,5 Gigawatt atau naik sebesar 3\% dibandingkan kapasitas pada tahun 2017. Kapasitas terpasang pembangkit listrik tahun 2018 sebagian besar berasal dari pembangkit yang bersumber energi dari fosil seperti batu bara 50\%, gas bumi 29\%, BBM 7\%, dan energi terbarukan (EBT) 14\% (Al Hakim, 2020a; Tim Sekretaris Jenderal Dewan Energi Nasional, 2019).

Hampir sebagian besar pembangkit listrik yang dikelola PLN yakni sebesar 43,2 Gigawatt (67\%) dan IPP hanya sebesar 14,9 Gigawatt (23\%). Sedangkan pembangkit listrik 
yang dibangkitkan oleh Private Power Utility (PPU) dan Izin Operasi (IO) non-BBM sebesar 2,4 Gigawatt (4\%) dan IPP 4,1 Gigawatt (6\%) (Tim Sekretaris Jenderal Dewan Energi Nasional, 2019). IPP (Independent Power Producer) sendiri artinya perusahaan produsen listrik swasta yang dibentuk oleh konsorsium untuk melakukan perjanjian PPA (perjanjian jual beli tenaga listrik, Power Purchase Agreement) dengan PLN (Listrik.org, 2006). Tahun 2018, produksi pembangkit listrik mencapai $283,8 \mathrm{TWh}$, dan itu semua sebagian besar dihasilkan dari pembangkit listrik berbahan bakar batu bara 56,4\%, pembangkit listrik berbahan bakar gas 20,2\%, dan BBM hanya 6,3\%, serta Energi Baru dan Terbarukan (EBT) sebesar 17,1\% (Tim Sekretaris Jenderal Dewan Energi Nasional, 2019).

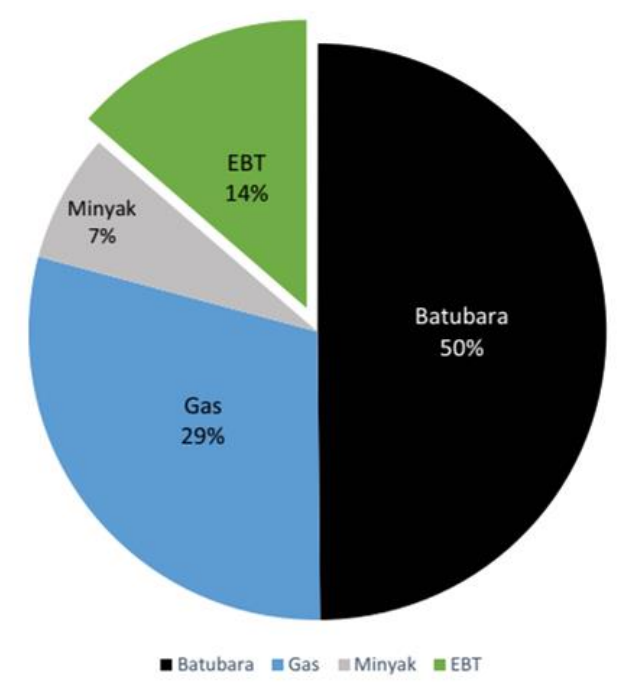

\section{Gambar 1. Kapasitas Terpasang Pembangkit Listrik per Jenis Sumber Energinya pada 2018}

(Sumber: Kementerian ESDM, 2018)

Listrik dari PLN dan pembangkit non PLN yang tersambung pada jaringan PLN (disebut on grid) disalurkan kepada konsumen rumah tangga sebesar $978.000 \mathrm{GWh}$ (42\%), sektor industri $769.000 \mathrm{GWh}(33 \%)$, komersial 595.000 GWh (25\%), dan untuk sektor transportasi (pengoperasian kereta komuter) konsumsinya sebesar $274 \mathrm{GWh}(0,12 \%)$ (Tim Sekretaris Jenderal Dewan Energi Nasional, 2019). 




Gambar 2. Penjualan Listrik di Indonesia pada 2018

(Sumber: Kementerian ESDM, 2018)

Sesuai dengan Peraturan Pemerintah No. 17 Tahun 1972, status Perusahaan Listrik Negara (PLN) ditetapkan sebagai Perusahaan Umum Listrik Negara dan sebagai Pemegang Kuasa Usaha Ketenagalistrikan (PKUK) dengan tugas menyediakan tenaga listrik bagi kepentingan umum. PLN memiliki moto "Listrik untuk Kehidupan yang Lebih Baik" (PT PLN, 2019).

\section{Sistem Distribusi Listrik di Indonesia}

Saat ini sistem distribusi listrik yang digunakan PLN secara umum menggunakan sistem sentralisasi listrik. Sistem ini ternyata dapat membawa dampak buruk dalam distribusi listrik di Indonesia, di antaranya menyebabkan banyaknya wilayah yang sulit di capai jaringan listrik dikarenakan faktor geologis suatu wilayah tersebut yang buruk dan meningkatnya kebutuhan energi listrik (Hasannuddin et al., 2017).

Usaha PLN untuk mencapai realisasi elektrifikasi nasional yang terus meningkat, menyebabkan PLN meningkatkan biaya investasi khususnya investasi pada transmisi, tetapi peningkatan biaya tersebut tidak diimbangi pertumbuhan konsumsi listrik yang cenderung tidak seimbang. Dampak dari tuntutan realisasi elektrifikasi nasional tersebut mempengaruhi finansial dari PLN per kuartal I Tahun 2019 total hutang PLN mencapai Rp 394,18 Triliun yang angkanya melonjak 1,7\% dibandingkan hutang pada akhir 2018 sebesar Rp 387,44 Triliun (CNN Indonesia, 2020).

\section{Pandemi Covid-19 dan Dampaknya di Indonesia}

Sejak ditetapkannya Covid-19 sebagai pandemi global karena telah menyebar hingga ke seluruh dunia (Al Hakim, 2020b; Al Hakim et al., 2020; Sulistyaningrum \& Al Hakim, 2020) berbagai persoalan yang timbul diakibatkan oleh adanya pandemi Covid-19 di Indonesia seperti pada sektor pendidikan (Sulistyaningrum \& Al Hakim, 2020), kesehatan (Lai et al., 2020), 
inovasi teknologi (Al Hakim, 2020b; Al Hakim et al., 2020; Vaishya et al., 2020; Yusuf et al., 2020), sosial dan ekonomi (Budastra, 2020) tak terkecuali terhadap naiknya tagihan listrik (Kompas, 2020).

Covid-19 yang disebabkan oleh virus Severe Acute Respiratory Syndrome-Corona Virus 2 (SARS-CoV-2) ini menyerang sistem pernapasan pada manusia dan dilaporkan dapat menular antar manusia satu dengan lainnya sehingga berbagai upaya untuk mencegah terjadinya penularan Covid-19 diperlukan berbagai pihak (Al Hakim et al., 2020). Karena dengan adanya kondisi pandemi Covid-19 di Indonesia, berbagai regulasi baru dari pemerintah diterapkan guna mencegah dan menanggulangi Covid-19 di Indonesia (Kemkes RI, 2020; Sulistyaningrum \& Al Hakim, 2020) dan akibat Covid-19 yang telah menyebar di Indonesia terdapat persoalan terkait naiknya tagihan listrik masyarakat akibat perubahan pola hidup yang lebih banyak menghabiskan waktu di rumah (Kompas, 2020; Okefinance, 2020).

\section{METODE PENELITIAN}

Metode penelitian yang digunakan yakni dengan metode penelitian kuantitatif dengan pendekatan deskripsi kuantitatif, teknik pengambilan sampel secara random sampling melalui jajak pendapat (survei) Google Form dengan rincian sebagai berikut :

\section{Jenis dan Sumber Data}

Jenis data berupa jajak pendapat menggunakan Google Form dan sumber data berasal dari responden-responden daring yang tersebar di berbagai wilayah di Indonesia. Pelaksanaan dilakukan pada 25 Juni s.d. 30 Juli 2020 termasuk studi literatur sebagai data sekunder. Kuesioner termasuk identitas responden, perilaku penggunaan listrik, dan jenis pelanggan listrik prabayar atau pasca bayar.

\section{Populasi dan Sampel}

Populasi yang kami gunakan berupa para pelanggan listrik PLN baik prabayar maupun pasca bayar, sedangkan sampel yang kami ambil secara daring (Google Form) sebanyak 137 responden secara acak di beberapa daerah di Indonesia.

\section{Evaluasi dan rekomendasi}

Setelah seluruh tahapan penelitian dilakukan diakhiri dengan evaluasi serta rekomendasirekomendasi berdasarkan hasil penelitian yang kami lakukan. 


\section{HASIL DAN PEMBAHASAN}

\section{Hasil Survei Google Form}

Berdasarkan hasil survei sebanyak 137 responden sebagian besar responden bekerja sebagai karyawan swasta $(24,1 \%)$ diikuti pegawai ASN $(22,6 \%)$, wirausaha $(12,4 \%)$, guru/pengajar non-ASN (10,9\%), freelancer $(8 \%)$, petani $(7,3 \%)$, pedagang $(5,8 \%)$, buruh $(5,8 \%)$, dan peneliti $(2,9 \%)$. Terkait dengan taraf pekerjaan, dapat mengakibatkan perbedaan penggunaan perangkat elektronik yang dapat meningkatkan perilaku konsumtif energi listrik tergantung taraf pekerjaannya (Rohi \& Luik, 2011). Seluruh responden tersebut sebagian besar mengalami kenaikan tagihan listrik $(90,5 \%)$, mungkin atau tidak yakin mengalami kenaikan tagihan listrik (6,6\%), dan sisanya menjawab tidak mengalami kenaikan tagihan listrik (2,9\%).

Selanjutnya berdasarkan jenis pelanggan apakah termasuk pelanggan prabayar atau pasca bayar, sebanyak $67,9 \%$ responden merupakan pelanggan prabayar, sedangkan sebanyak $32,1 \%$ responden merupakan pelanggan pasca bayar atau menggunakan pulsa rekening. Terkait dengan pemakaian listrik dan pembayaran tagihan listrik setiap bulannya dapat menjelaskan efisiensi pemakaian energi listrik (Rohi \& Luik, 2011). Sebagian besar responden berada di depan komputer atau laptop dan terhubung ke internet (kuliah, bekerja, aktivitas daring lainnya) sebanyak $28,5 \%$, diikuti aktivitas berkebun sebanyak $17,5 \%$, memasak, atau mencoba masakan baru dan menonton TV atau film masing-masing sebanyak 11,7\%, membuka platform daring multimedia sebanyak $9,5 \%$, olahraga sebanyak $5,1 \%$, dan sisanya kegiatan-kegiatan lain $0,7 \%$.

Selanjutnya, peneliti memberikan kategori perilaku aktivitas manusia sehari-hari selama pandemi Covid-19 yang dikelompokkan menjadi lima kelompok: A1, A2, A3, A4, dan A5. Peneliti mengambil beberapa perilaku yang lebih banyak dilakukan selama pandemi Covid-19 baik termasuk perilaku yang menggunakan energi listrik maupun perilaku yang tidak menggunakan energi listrik. Setiap perilaku berdasarkan kuesioner pertanyaan yang terdapat pada Google Form dan kemudian peneliti ubah secara kuantitatif dengan mencari nilai mean. Kemudian setiap kelompok perilaku memiliki makna tertentu seperti kelompok A1 yakni perilaku-perilaku yang menggunakan perangkat elektronik atau segala aktivitas yang menggunakan banyak listrik. Kelompok perilaku A2 yakni perilaku-perilaku dengan penggunaan perangkat elektronik sewajarnya atau segala aktivitas yang menggunakan listrik dengan normal. Kelompok perilaku A3 yakni perilaku-perilaku dengan penggunaan perangkat elektronik yang jarang atau segala aktivitas yang jarang menggunakan listrik. Kelompok perilaku A4 yakni perilaku-perilaku dengan tidak menggunakan perangkat elektronik atau segala aktivitas yang tidak menggunakan listrik. Kelompok perilaku A5 yakni perilaku-perilaku dengan sama sekali tidak menggunakan perangkat elektronik atau segala aktivitas yang sama sekali tidak menggunakan listrik. Secara lebih detail dapat dilihat pada Tabel 1. 
Tabel 1.

Perilaku Aktivitas Sehari-hari Manusia Selama Pandemi Covid-19

\begin{tabular}{clcc}
\hline Nomor & \multicolumn{1}{c}{ Perilaku Aktivitas } & Mean & Kelompok \\
\hline 1. & Menonton TV atau film & 0,117 & A1 \\
2. & Berada depan komputer dan terhubung ke internet \& WFH & 0,300 & A1 \\
3. & Bermain game online & 0,015 & A1 \\
4. & Membaca bacaan elektronik & 0,051 & A1 \\
5. & Membuka platform daring multimedia & 0,095 & A1 \\
6. & Olahraga & 0,051 & A2 \\
7. & Memasak & 0,117 & A2 \\
8. & Berkebun dengan alat-alat berdaya listrik & 0,175 & A2 \\
9. & Sering menggunakan ponsel pintar & 0,022 & A3 \\
10. & Aktivitas harian seperti biasa sebelum pandemi & 0,015 & A3 \\
11. & Berjualan atau memiliki toko & 0,022 & A4 \\
12. & Pulang kampung dan rumah dikosongkan & 0,007 & A5 \\
13. & Tidak menggunakan listrik & 0,015 & A5 \\
\hline
\end{tabular}

Sumber: Data diolah (2020)

Karena nilai mean setiap perilaku telah didapatkan, sebagaimana tercantum dalam Tabel 1, kemudian setiap kelompok akan dihitung bobot mean kelompok kemudian dapat ditentukan nilai interval kelompok dari bobot mean kelompok, dapat dilihat pada Tabel 2.

Tabel 2.

Bobot Mean Kelompok

\begin{tabular}{cc}
\hline Kelompok & Bobot Mean Kelompok \\
\hline A1 & 2,883 \\
A2 & 1,372 \\
A3 & 0,109 \\
A4 & 0,044 \\
A5 & 0,022 \\
\hline Nilai Interval kelompok $=0,8$ \\
\hline \multicolumn{2}{r}{ Sumber: Data diolah $(2020)$}
\end{tabular}

Berdasarkan Tabel 2 maka perilaku aktivitas sehari-hari manusia selama pandemi Covid19 pada Tabel 1 dapat dikategorikan menjadi lima kelompok yakni A1, A2, A3, A4, A5. Kelompok perilaku A1 yakni perilaku menggunakan perangkat elektronik atau segala aktivitas yang menggunakan banyak listrik. Rata-rata (mean) kelompok A1 yakni 2.883. Kelompok perilaku A2 yakni perilaku dengan penggunaan perangkat elektronik sewajarnya atau segala aktivitas yang menggunakan listrik dengan normal. Rata-rata (mean) dari kelompok A2 yakni 1.372. Kelompok perilaku A3 yakni perilaku dengan penggunaan perangkat elektronik yang jarang atau segala aktivitas yang jarang menggunakan listrik. Rata-rata (mean) dari kelompok A3 yakni 0.109. Kelompok perilaku A4 yakni perilaku dengan tidak menggunakan perangkat elektronik atau segala aktivitas yang tidak menggunakan listrik. Rata-rata (mean) dari kelompok A4 yakni 0.044. Kelompok perilaku A5 yakni perilaku dengan sama sekali tidak menggunakan 
perangkat elektronik atau segala aktivitas yang sama sekali tidak menggunakan listrik. Rata-rata (mean) dari kelompok A5 yakni 0.022.

Setelah didapatkan nilai interval sebesar 0.8 (pada Tabel 2), sehingga data kuantitatifnya secara deskripsi terdiri atas SB (sangat baik berpengaruh terhadap tagihan listrik) berkisar 4,215,00; B (baik berpengaruh terhadap tagihan listrik) berkisar 3,41-4,20; C (cukup berpengaruh terhadap tagihan listrik) berkisar 2,61-3,40; K (kurang berpengaruh terhadap tagihan listrik) berkisar 1,81-2,60; SK (sangat kurang berpengaruh terhadap tagihan listrik) berkisar 1,00-1,80; dan null (tidak berpengaruh sama sekali dan termasuk di bawah interval terendah) untuk mean kelompok $<1,00$.

\section{Deskriptif Mean Kelompok Aktivitas Sehari-hari Manusia}

Hasil akhirnya yakni perilaku kategori A1 $(2,883)$ berarti cukup, artinya perilaku yang tergolong dalam kategori A1 lebih banyak menggunakan energi listrik cukup berpengaruh terhadap tagihan listrik. Kategori A2 $(1,372)$ berarti sangat kurang, artinya perilaku yang tergolong dalam kategori A2 penggunaan energi listrik masih dalam keadaan sewajarnya sangat kurang berpengaruh terhadap tagihan listrik. Kategori A3, A4, dan A5 null, artinya perilaku yang termasuk ke dalam kategori A3, A4, dan A5 tidak berpengaruh sama sekali terhadap penggunaan energi listrik. Secara lebih rinci dapat dilihat pada Tabel 3.

Tabel 3.

Hasil Penggolongan Interval Kelompok

\begin{tabular}{ccc}
\hline Kelompok & Bobot Mean Kelompok & Deskripsi Kuantitatif \\
\hline A1 & 2,883 & $\mathrm{C}$ \\
A2 & 1,372 & SK \\
A3 & 0,109 & null \\
A4 & 0,044 & null \\
A5 & 0,022 & null \\
\hline
\end{tabular}

Sumber: Data diolah (2020)

Disisi lain, selama pandemi Covid-19 kenaikan tagihan listrik bukan dikarenakan tarif listriknya yang meningkat, namun karena akumulasi dari tagihan di bulan sebelumnya, tepatnya sebelum awal pandemi Covid-19 muncul, karena akumulasi tagihan itulah terkesan terjadi kenaikan tarif listrik yang ditagih, padahal yang terjadi ialah naiknya tagihan listrik akibat pemakaian sebelumnya yang belum dibayarkan. PLN pun sudah mengeluarkan kebijakan cicilan pembayaran tagihan hingga September 2020 dan tidak adanya kenaikan tarif listrik (Okefinance, 2020). Ajakan untuk masyarakat supaya lebih menghemat energi disisi pemerintah meningkatkan konversi energi ke energi hijau (Chauhan \& Chauhan, 2019) seperti di Indonesia menghemat energi hingga 10\% perlu dilakukan (Dirjen EBTKE Kementerian ESDM RI, 2016) mengingat kondisi pandemi saat ini yang mengharuskan aktivitas-aktivitas dari rumah terutama Work From Home (WFH) yang mengakibatkan peningkatan pola konsumtif energi listrik dari 
rumah sebesar 6\% (Detikfinance, 2020), disisi lain hemat listrik dapat menyelamatkan lingkungan (Al Hakim, 2020a; Rohi \& Luik, 2011).

Beberapa cara agar pemakaian listrik dapat lebih hemat yakni mengedepankan kesadaran pada diri sendiri untuk lebih menghemat energi serta memperkaya wawasan tentang hemat listrik, kesadaran untuk menggunakan peralatan-peralatan yang hemat listrik, dan selalu mengontrol meteran listrik yang ada di rumah (Rohi \& Luik, 2011). Selain itu, upaya-upaya seperti mengurangi penggunaan lampu pada siang hari, mengurangi pemakaian pendingin udara, menghemat air yang menggunakan pompa, mematikan TV ketika tidak digunakan, menghindari penggunaan alat-alat elektronik yang memiliki fitur stand-by, serta membatasi aktivitas daring dan streaming di internet (Detikfinance, 2020). PLN juga telah mengembangkan pembangkit, transmisi, distribusi listrik, dan selalu melakukan pemeliharaan dan perbaikan jaringan listrik sehingga meminimalisir terjadinya gangguan listrik (Nusabali, 2018), serta berupaya mengurangi kerugian daya pada jaringan listrik (Hasannuddin et al., 2017).

\section{KESIMPULAN}

Berdasarkan hasil penelitian dapat disimpulkan bahwa sebanyak 137 responden mengalami kenaikan tagihan sebanyak 90,5\% dengan 67,9\% responden merupakan pelanggan prabayar, dan kenaikan tagihan listrik yang diakibatkan oleh aktivitas-aktivitas yang lebih mengonsumsi daya listrik (kategori A1 sebesar 2,883 yang berarti cukup berpengaruh terhadap tagihan listrik), serta perlunya kesadaran masyarakat akan upaya-upaya untuk menghemat energi listrik selama pandemi Covid-19 (Work From Home), dan selalu melakukan pengecekan berkala pada penggunaan listrik di rumah.

\section{UCAPAN TERIMA KASIH}

Penulis mengucapkan terima kasih kepada DEM Indonesia, Tim Riset dan Kajian DEM Indonesia, dan para pejuang kedaulatan energi di Indonesia yang telah membantu jalannya penelitian dengan baik. 


\section{DAFTAR PUSTAKA}

Al Hakim, R. R. (2020a). Model Energi Indonesia, Tinjauan Potensi Energi Terbarukan untuk Ketahanan Energi di Indonesia: Sebuah Ulasan. ANDASIH Jurnal Pengabdian Kepada Masyarakat, 1(1), 111.

Al Hakim, R. R. (2020b). Pencegahan Penularan Covid-19 Berbasis Aplikasi Android Sebagai Implementasi Kegiatan KKN Tematik Covid-19 di Sokanegara Purwokerto Banyumas. Community Engagement and Emergence Journal (CEEJ), 2(1), 7-13. https://doi.org/10.37385/ceej.v2i1.125

Al Hakim, R. R., Rusdi, E., \& Setiawan, M. A. (2020). Android Based Expert System Application for Diagnose COVID-19 Disease: Cases Study of Banyumas Regency. Journal of Intelligent Computing \& Health Informatics, 1(2), 1-13. https://doi.org/10.26714/jichi.v1i2.5958

Budastra, I. K. (2020). Dampak Sosial Ekonomi Covid-19 Dan Program Potensial Untuk Penanganannya : Studi Kasus Di Kabupaten Lombok Barat Socio-Economic Impacts of Covid-19 and Potential Programs for Mitigation: a Case Study in Lombok Barat District. Jurnal Agrimansion, 20(1), 48-57.

Chauhan, R. K., \& Chauhan, K. (2019). Building automation system for grid-connected home to optimize energy consumption and electricity bill. Journal of Building Engineering, 21(October 2018), 409420. https://doi.org/10.1016/j.jobe.2018.10.032

CNN Indonesia. (2020). Per Kuartal I, Utang PLN Naik Jadi Rp394 Triliun.

Detikfinance. (2020). 7 Langkah Hemat Listrik Selama WFH.

Dirjen EBTKE Kementerian ESDM RI. (2016). Pemerintah Ajak Masyarakat Hemat Energi Kementerian ESDM Republik Indonesia.

Đurišić, V., Rogić, S., Smolović, J. C., \& Radonjić, M. (2019). Determinants of household electrical energy consumption: Evidences and suggestions with application to Montenegro. Energy Reports, September. https://doi.org/10.1016/j.egyr.2019.10.039

Hasannuddin, T., Aiyub, S., \& Pulungan, A. B. (2017). EFISIENSI PENGGUNAAN ENERGI LISTRIK PADA SISTEM INTERKONEKSI $150 \mathrm{kV}$ NANGGROE ACEH DARUSSALAM MENGGUNAKAN DISTRIBUTED GENERATION. JURNAL LITEK: Jurnal Listrik Telekomunikasi Elektronika, 14(1), 13-17.

Kementerian ESDM. (2018). Handbook Of Energy \& Economic Statistics Of Indonesia 2018 Final Edition. In Ministry of Energy and Mineral Resources.

Kemkes RI. (2020). Lakukan Protokol Kesehatan Ini Jika Mengalami Gejala Covid-19. Kementerian Kesehatan Republik Indonesia.

Kompas. (2020). Tagihan Listrik Naik padahal Pemakaian Menurun? Kemungkinan Ini Penyebabnya Menurut PLN Halaman all - Kompas.com.

Lai, C. C., Shih, T. P., Ko, W. C., Tang, H. J., \& Hsueh, P. R. (2020). Severe acute respiratory syndrome coronavirus 2 (SARS-CoV-2) and coronavirus disease-2019 (COVID-19): The epidemic and the challenges. International Journal of Antimicrobial Agents. https://doi.org/10.1016/j.ijantimicag.2020.105924

Listrik.org. (2006). IPP \& PPA - Listrik.org.

Lu, R., Zhao, X., Li, J., Niu, P., Yang, B., Wu, H., Wang, W., Song, H., Huang, B., Zhu, N., Bi, Y., Ma, X., Zhan, F., Wang, L., Hu, T., Zhou, H., Hu, Z., Zhou, W., Zhao, L., ... Tan, W. (2020). Genomic characterisation and epidemiology of 2019 novel coronavirus: implications for virus origins and receptor binding. The Lancet, 395(10224), 565-574. https://doi.org/10.1016/S0140-6736(20)30251- 
8

Nusabali. (2018). PLN Minta Masyarakat Hemat Listrik.

Okefinance. (2020). Terungkap Biang Kerok Penyebab Tagihan Listrik Melonjak hingga 100\%: Okezone Economy.

PT PLN. (2019). Profil Perusahaan - PT PLN (Persero). PT PLN (Persero).

Rohi, D., \& Luik, J. E. (2011). Kesadaran Masyarakat Surabaya untuk Memiliki Gaya Hidup Ramah Lingkungan “ Green Living” Melalui Menghemat Penggunaan Energi Listrik. LPPM Universitas Kristen Petra, 1-17.

Sulistyaningrum, D., \& Al Hakim, R. R. (2020). Pendampingan Pembelajaran Siswa Melalui Teknologi Informasi Selama Pandemi Covid-19: Studi Kasus KKN Tematik Covid-19. ANDASIH Jurnal Pengabdian Kepada Masyarakat, 1(02), 1-7.

Tegor, U. H. (2017). Compensation analysis in relationship moderation between transformational leadership style and work environment on the employee performance. Russian Journal of Agricultural and Socio-Economic Sciences, 71(11), 312-323. doi:10.18551/rjoas.2017-11.40

Tim Sekretaris Jenderal Dewan Energi Nasional. (2019). Indonesia Energy Out Look 2019. Dewan Energi Nasional.

Vaishya, R., Javaid, M., Khan, I. H., \& Haleem, A. (2020). Artificial Intelligence (AI) applications for COVID-19 pandemic. Diabetes and Metabolic Syndrome: Clinical Research and Reviews, 14(4), 337-339. https://doi.org/10.1016/j.dsx.2020.04.012

Yuliati, L. N., \& Nurasrina, I. (2012). Pesan, Kesadaran, dan Perilaku Hemat Listrik Rumah Tangga. Jurnal Ilmu Keluarga Dan Konsumen, 5(1), 88-95. https://doi.org/10.24156/jikk.2012.5.1.88

Yusuf, E., Mohammed, M. N., Arif, A. S., Al-Zubaidi, S., Al-Sanjary, O. I., \& Sairah, A. K. (2020). 2019 Novel Coronavirus Disease (Covid-19): Design and Development of Disinfectant Fogging System Using IoT Based Drone Technology. Revista Argentina de Clínica Psicológica, 29(5), 221-227. https://doi.org/10.24205/03276716.2020.1023 